\title{
Notkun ósæðardælu við kransæðahjáveituaðgerðir
}

\section{Sunna Lu Xi Gunnarsdóttir ${ }^{1}$ Erla Liu Ting Gunnarsdóttir ${ }^{1}$ Alexandra Aldís Heimisdóttir ${ }^{1}$ Sunna Rún Heiðarsdóttir ${ }^{1}$ Sólveig Helgadóttir ${ }^{2}$

Martin Ingi Sigurðsson
Tómas Guðbjartsson
To,

${ }^{1}$ Læknadeild Háskóla Íslands, ${ }^{2}$ svæfinga- og gjörgæsludeild Akademíska sjúkrahússins í Uppsölum, Svípjóð, ${ }^{3}$ svæfinga- og gjörgæsludeild, ${ }^{4}$ hjarta- og lungnaskurðdeild Landspítala.

Höfundar eru læknanemar við læknadeild Háskóla Íslands nema Martin Ingi Sigurðsson, Tómas Guðbjartsson og Sólveig Helgadóttir sem eru læknar.

Fyrirspurnum svarar Tómas Guðbjartsson, tomasgudbjartsson@hotmail.com

\section{Inngangur}

Kransæðahjáveituaðgerð er algengasta opna hjartaaðgerðin á Íslandi ${ }^{1}$ og er oftast framkvæmd sem valaðgerð en stundum brátt í kjölfar nýlegs hjartadreps, óstöðugra brjóstverkja eða vegna hjartabilunar. ${ }^{2}$ Hjá sjúklingum sem parfnast bráđrar aðgerðar, eða hafa verulega skerðingu á slegilstarfsemi fyrir eða eftir aðgerð getur komið til greina að beita meðferð með ósæðardælu (intra aortic balloon pump, IABP). ${ }^{3}$ Ósæðardæla er helíumfyllt plastblaðra og slanga sem tengd er dælu sem blæs upp og tæmir blöðruna, oftast í takt við hjartalínurit en í takt við slagæðakúrfu ef óregla er mikil á hjartslætti. ${ }^{4}$ Blöðrunni er komið fyrir gegnum náraslagæð pannig að endi hennar sé í fallhluta ósæðar, rétt neðan við vinstri viðbeinsslagæð (left subclavian artery). Blaðran penst út við upphaf panbils (diastole) sem eykur blóðflæði til kransæða sem undir venjulegum kringumstæðum er langmest í panbili. Blaðran dregst síðan saman í slagbili (systole) sem minnkar eftirpjöppun (afterload) hjartans og auðveldar pví að tæma sig (sjá mynd 1.) Heildaráhrifin eru pví pau að ósæðardælan eykur framboð súrefnis til hjartavöðvans og minnkar súrefnispörf hans. ${ }^{5}$

Notkun ósæðardælu geta fylgt alvarlegir fylgikvillar eins og blæðingar, sýkingar og blóðpurrð í ganglimum. ${ }^{6,7}$ Auk pess hefur gagn af notkun hennar verið dregið í efa. ${ }^{8}$ Í slembuðu SHOCK II-samanburðarrannsókninni frá 2012 var ekki sýnt fram á að

\section{Á G R I P}

\section{INNGANGUR}

Ósæðardæla eykur blóðflæði um kransæðar í panbili og auðveldar vinnu hjartans við að tæma sig í slagbili. Hún er einkum notuð við bráđa hjartabilun, en í minnkandi mæli við hjartabilun eftir opnar hjartaskurðaðgerðir par sem umdeilt er hvort notkun hennar bæti horfur sjúklinga. Tilgangur pessarar rannsóknar var að kanna tíðni, ábendingar og árangur notkunar ósæðardælu í tengslum við kransæðahjáveituaðgerðir á Íslandi.

\section{EFNIVIĐUR OG AĐFERĐIR}

Rannsóknin var afturskyggn og náđi til 2177 sjúklinga sem gengust undir kransæðahjáveituađgerð á Landspítala á tímabilinu 20012018. Sjúklingar sem fengu ósæðardælu voru bornir saman við sjúklinga í viðmiðunarhópi með ein- og fjölpáttagreiningu. Langtímalifun og langtímafylgikvillar voru áætluð með aðferð KaplanMeiers.

\section{NIĐURSTÖĐUR}

Alls fengu 99 (4,5\%) sjúklingar ósæðardælu og var tíðnin hæst árið 2006 (8,9\%) en lægst 2001 (1,7\%) og breyttist ekki marktækt yfir rannsóknartímabilið $(p=0,90)$. Flestir fengu ósæðardælu fyrir (58,6\%) eða í (34,3\%) aðgerð, en aðeins 6,1\% eftir aðgerð. Heildartíðni fylgikvilla var $14,1 \%$ og var blæðing frá ísetningarstað algengasti kvillinn (4,0\%). Tíoni fylgikvilla og 30 daga dánartíoni var hærri í ósæðardæluhópi en viðmiðunarhópi (22,2\% á móti 1,3\%, p<0,001) og heildarlifun 5 árum eftir aðgerð reyndist síðri (56,4\% á móti 91,5\%, 95\% ÖB: 0,47-0,67) sem og 5 ára MACCE-frí lifun (46,9\% á móti $83,0 \%, 95 \%$ ÖB: 0,38-0,58).

\section{ÁLYKTUN}

Innan við 5\% sjúklinga fengu ósæðardælu í tengslum við kransæðahjáveitu á Íslandi og hefur hlutfallið lítið breyst á síðastliðnum 18 árum. Tíđni fylgikvilla og 30 daga dánartíðni var hæri hjá sjúklingum sem fengu ósæðardælu og bæði langtíma- og MACCEfrí lifun peirra umtalsvert síðri, sem sennilega skýrist af alvarlegra sjúkdómsástandi peirra sem fengu dæluna.

notkun ósæðardælu bætti lifun hjá sjúklingum með bráða hjartabilun eftir kransæðastíflu. ${ }^{9}$ Fleiri rannsóknir hafa kannað árangur ósæðardælu hjá sjúklingum í losti eftir hjartadrep ${ }^{10,11}$ en færri rannsóknir hafa kannað árangur ósæðardælumeðferðar hjá sjúklingum í tengslum við hjartaaðgerðir, og pá sérstaklega eftir kransæðahjáveitu. ${ }^{12}$ Í nýlegri safngreiningu var pó sýnt fram á að notkun ósæðardælu fyrir hjáveituaðgerð lækkaði 30 daga dánar- 


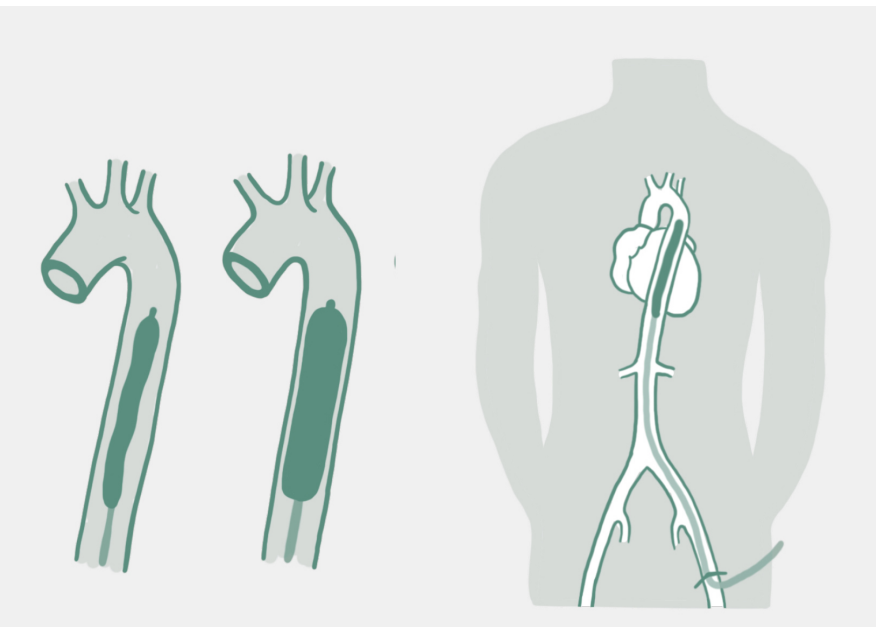

Mynd 1. Ósæðardælu er yfirleitt komið fyrir í gegnum náraslagæð og er belgurinn staðsettur neðan vinstri viðbeinsslagæðar. Blaðran dregst saman í slagbili en penst út í panbili. Mynd: Rán Flygenring og Guðbjörg Tómasdóttir.

tíðni hjá há-áhættu sjúklingum. ${ }^{13}$ Önnur rannsókn sýndi að notkun ósæðardælu fyrir kransæðahjáveitu hjá há-áhættu sjúklingum stytti sjúkrahúsdvöl og lækkaði 30 daga dánartíðni eftir hjáveituaðgerð. ${ }^{3}$ Hins vegar eru fáar rannsóknir á langtímahorfum sjúklinga sem fá ósæðardælu í tengslum við kransæðahjáveitu. ${ }^{3}$

Ekki eru til rannsóknir á notkun ósæðardælu við hjartaaðgerðir á Íslandi. Markmið rannsóknarinnar var pví að kanna tíðni og ábendingar fyrir notkun dælunnar hjá sjúklingum sem gangast undir kransæðahjáveitu, en jafnframt að skrá fylgikvilla meðferðarinnar og horfur sjúklinga til lengri og skemmri tíma.

\section{Efniviður og aðferðir}

Öll tilskilin leyfi lágu fyrir áđur en rannsóknin hófst, frá Persónuvernd, vísindasiðanefnd (VSN 10-009) og framkvæmdastjóra lækninga á Landspítala.

Rannsóknin var afturskyggn og nádi til 2177 sjúklinga, 18 ára og eldri, sem gengust undir kransæðahjáveituaðgerð eingöngu (isolated $C A B G$ ) á Landspítala frá 1. janúar 2001 til 31. desember 2018. Stuðst var við gagnagrunn hjarta- og lungnaskurðdeildar Landspítala en í hann eru skráđar helstu upplýsingar um alla pá sjúklinga sem gengust undir kransæðahjáveituaðgerð á Íslandi á tímabilinu. Gerð var leit að sjúklingum í aðgerðarskrá hjartaog lungnaskurðdeildar í sjúklingabókhaldi Landspítala par sem leitað var að aðgerðarnúmerum fyrir kransæðahjáveituaðgerð (FNSA00, FNSC10, FNSC20, FNSC30) og aðgerðir par sem notuð var hjarta- og lungnavél (FZSA00, FZSA10). Af peim sjúklingum voru aðeins peir teknir með í rannsóknina sem gengust undir sína fyrstu kransæðahjáveituaðgerð og par sem önnur hjartaaðgerð (til dæmis lokuskipti) var ekki framkvæmd á sama tíma.

Í fyrri greinum rannsóknarhópsins í Læknablađinu er ítarlegri lýsing á gagnagrunninum. ${ }^{14}$ Klínískar upplýsingar voru fengnar úr sjúkraskrám og aðgerðarlýsingum. Fyrir hvern sjúkling voru skráðar tæplega 170 breytur í rafræna Excel-skrá (Microsoft Corp, Redmond, WA), par á meðal grunnupplýsingar um sérhvern sjúkling, áhættupættir fyrir hjarta- og æðasjúkdóma og ýmsir pættir varðandi fyrra heilsufar. Jafnframt voru einkenni núverandi sjúkdóms skráð og metin samkvæmt CCS-flokkun (Canadian Cardiovascular Society) á hjartaöng og NYHA-flokkun (New York Heart Association) á hjartabilun. ${ }^{15,16}$ EuroSCORE II var reiknað fyrir hvern sjúkling ${ }^{17}$ og útbreiðsla kransæðasjúkdóms var metin samkvæmt niðurstöðum úr kransæðapræðingu. Upplýsingar um útstreymisbrot (ejection fraction, $\mathrm{EF}$ ) vinstri slegils fengust út frá svörum hjartaómunar, en skert útstreymisbrot var skilgreint sem $\leq 30 \%$. Par að auki voru færðar í grunninn upplýsingar um lyf sem sjúklingar tóku fyrir aðgerð og atriði tengd aðgerðinni. Loks var kannað hvort nota purfti ósæðardælu í tengslum við hjáveituaðgerðina og hvort dælunni var komið fyrir í upphafi aðgerðar, í aðgerð eða eftir hana. Upplýsingar um ástand sjúklinga eftir aðgerð voru færðar í grunninn og fylgikvillar tengdir aðgerðinni skráðir niður. Fylgikvillum var skipt í minniháttar og alvarlega en peir hafa verið skilgreindir í eldri greinum úr sama efniviði. ${ }^{14}$ Auk pess voru fylgikvillar sem tengdust ósæðardælunni skráðir niður sérstaklega, en til peirra töldust meðal annars blæðingar frá nára, blóðpurrð í útlimum, blóðflögufæð (thrombocytopenia), sýkingar á ísetningarstað og rof á blöðru ósæðardælunnar. Loks voru langtímafylgikvillar sem tengdust hjarta- og æðakerfinu skráðir, en til peirra töldust atvik eins og kransæðastífla, heilablóðfall, kransæðavíkkun, endurkransæðahjáveituaðgerð (re-CABG) og dauði, sem áttu sér stað meira en 30 dögum eftir aðgerð. Pessar breytur voru teknar saman í einn sameiginlegan endapunkt sem kallaðist MACCE (major adverse cardiac and cerebrovascular event).

Sjúklingum var skipt í tvo hópa; annars vegar sjúklinga sem fengu ósæðardælu í tengslum við kransæðahjáveituaðgerðina, og hins vegar viðmiðunarhóp. Hóparnir voru bornir saman með tilliti til ýmissa bakgrunnspátta auk áhættupátta kransæðasjúkdóms. Auk pess var gerður samanburður milli ára á tíðni notkunar ósæðardælu og kannaður fjöldi peirra sem fengu dæluna í upphafi aðgerðar, í aðgerð og eftir hana. Horfur sjúklinga voru kannaðar með pví að bera saman ósæðardælu- og viðmiðunarhóp og pá út frá bæði 30 daga dánartíðni og langtímalifun. Einnig var litið á tíðni fylgikvilla eftir aðgerð. Eftirfylgd miðaðist við 31. desember 2018 og var miðgildi eftirfylgdar 101,1 mánuður (bil: 0,0-215,9). Dánarorsakir auk upplýsingar um dánardag fengust úr dánarmeinaskrá Embættis landlæknis. Upplýsingar um langtímafylgikvilla fengust úr sjúkraskrám í öllum helstu heilbrigðisumdæmum landsins.

Við útreikninga var notað tölfræðiforritið $\mathrm{R}$, útgáfa 3.5 .2 (R Foundation for Statistical Computing, Vín, Austurríki) með Rstudio, útgáfu 1.1.462 fyrir MAC. ${ }^{18}$ Talnabreytum var lýst með meðaltölum \pm staðalfrávik og flokkabreytum með hlutföllum. Til að meta hvort notkun ósæðardælu breyttist með tíma var notuð Poisson-aðhvarfsgreining. Tengsl ísetningar ósæðardælu við hverja breytu var metin með viðeigandi tilgátuprófum og miðaðist tölfræðileg marktækni við p-gildi $<0,05$. Talnabreytur voru bornar saman með t-prófi. Fyrir flokkabreytur voru breyturnar bornar saman með kí-kvaðrat prófi eða Fisher exact prófi eftir pví sem við átti. Til að meta áhættupætti fyrir notkun ósæðardælu var gerð lógistísk aðhvarfsgreining (logistic regression). Inn í líkanið voru settar pær breytur sem reyndust marktækar í einpátta greiningu og helstu breytur úr sambærilegum eldri greinum. Spágeta upphaflega líkansins var síðan metin og breytur felldar út með prepaðri valaðferð par til endanlegt líkan fékkst. Heildarlangtímalifun og 


\begin{tabular}{|c|c|c|c|}
\hline & $\begin{array}{l}\text { Ósæðardælu- } \\
\text { hópur } \\
(n=99)\end{array}$ & $\begin{array}{l}\text { Við̃miðunar- } \\
\text { hópur } \\
\text { (n = 2078) }\end{array}$ & p-gildi \\
\hline Kvenkyn & $30(30,3)$ & $357(17,2)$ & 0,001 \\
\hline Aldur (ár) & $67,8 \pm 11,5$ & $66,4 \pm 9,2$ & 0,147 \\
\hline Líkamspyngdarstuðull $\left(\mathrm{kg} / \mathrm{m}^{2}\right)^{\mathrm{a}}$ & $27,5 \pm 5,5$ & $28,4 \pm 4,4$ & 0,052 \\
\hline \multicolumn{4}{|l|}{ Fyrri saga um } \\
\hline Hjartabilun & $51(51,5)$ & $240(11,6)$ & $<0,001$ \\
\hline Nýlegt hjartaáfall ${ }^{b}$ & $66(66,7)$ & $563(27,1)$ & $<0,001$ \\
\hline Hjartaáfall & $28(28,3)$ & $491(23,6)$ & 0,198 \\
\hline Takttruflanir & $8(8,1)$ & $236(11,4)$ & 0,396 \\
\hline Lokusjúkdóma & $6(6,1)$ & $68(3,3)$ & 0,226 \\
\hline Útæðasjúkdóm & $3(5,6)$ & $73(6,1)$ & 1,000 \\
\hline Skert nýrnastarfsemid & $8(10,0)$ & $99(5,6)$ & 0,165 \\
\hline Langvinn lungnateppa $^{e}$ & $10(10,4)$ & $148(7,1)$ & 0,316 \\
\hline $\begin{array}{l}\text { Saga um kransæðavíkkun með/ } \\
\text { án stoðnets }\end{array}$ & $11(11,1)$ & $481(23,2)$ & 0,007 \\
\hline Útbreiðsla kransæðasjúkdóms & & & 0,884 \\
\hline Einnar æðar sjúkdómur & $2(2,0)$ & $51(2,5)$ & \\
\hline Tveggja æða sjúkdómur & $14(14,1)$ & $350(16,8)$ & \\
\hline Priggja æða sjúkdómur & $83(83,8)$ & $1676(80,7)$ & \\
\hline $\begin{array}{l}\text { Priggja æða sjúkdómur og/ } \\
\text { eða vinstri höfuððstofnsprengsli }\end{array}$ & $88(88,9)$ & $1851(89,1)$ & 1,000 \\
\hline Útstreymisbrot ${ }^{\dagger}$ vinstri slegils & & & $<0,001$ \\
\hline$\leq 30 \%$ & $39(43,8)$ & $70(3,5)$ & \\
\hline $31-50 \%$ & $30(33,7)$ & $598(29,6)$ & \\
\hline$>50 \%$ & $20(22,5)$ & $1354(67,0)$ & \\
\hline CCS-flokkur9 III/IV & $89(89,9)$ & $1495(71,9)$ & $<0,001$ \\
\hline NYHA-flokkurh III/IV & $83(83,8)$ & $1224(58,9)$ & $<0,001$ \\
\hline Blóðrauði fyrir aðgerð (g/L) & $137 \pm 17$ & $141 \pm 14$ & 0,005 \\
\hline EuroSCORE II & $8,1 \pm 7,4$ & $2,2 \pm 2,8$ & $<0,001$ \\
\hline
\end{tabular}

aUpplýsingar um LPS vantaði hjá 58 sjúklingum. 'Nýlegt hjartaáfall var skilgreint sem hjartaáfall innan 90 daga fyrir aðgerð. ‘Upplýsingar um útæđasjúkdóm vantaði hjá 927 sjúklingum, đnýrnastarfsemi hjá 338 sjúklingum, elangvinna lungnateppu hjá 11 sjúklingum, 'útstreymisbrot hjá 66 sjúklingum, ${ }^{9} \mathrm{CCS}$-flokk hjá 21 sjúklingi og ${ }^{\text {} N Y H A-~}$ flokk hjá 311 sjúklingum.

MACCE-frí lifun voru reiknaðar út með aðferð Kaplan-Meiers og hóparnir bornir saman með log-rank prófi.

Tölfræðipakkinn Matchit í R var notaður við gerð áhættuskorspörunar (propensity score matching) til að bera saman sjúklinga sem fá dælu við sambærilega sjúklinga. Pörunin tók til allra pátta sem aðgreindu hópana tvo fyrir aðgerð, pað er bakgrunnspátta sjúklinga auk áhættupátta kransæðasjúkdóms. Notaður var Nearest neighbour algóripiminn og reynd var pörun sem tryggir að staðlaður munur á pörunarbreytunum (standardized mean difference) væri undir 0,1. Engir sjúklingar úr viðmiðunarhópnum reyndust uppfylla pessi skilyrði svo ekki var unnt að gera samanburð á lifun hópsins og viðmiðunarhóps.

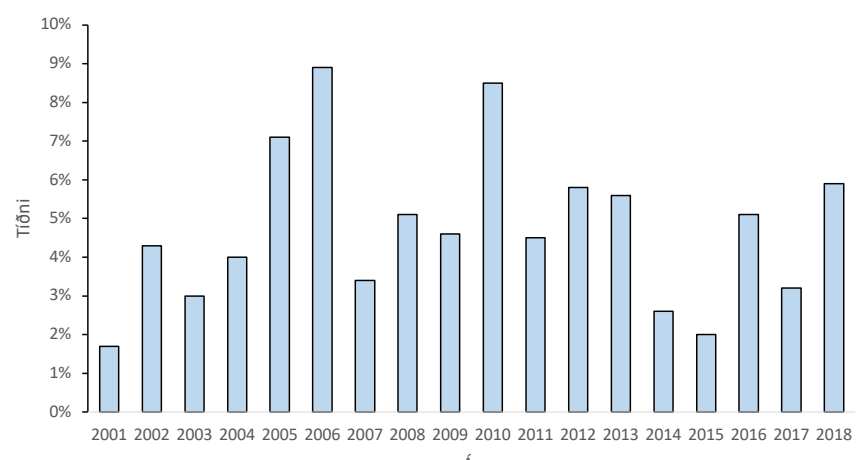

Mynd 2a. Hlutfall sjúklinga sem fengu ósæðardælu í tengslum við hjartaaðgerð skipt eftir árum yfir tímabilið 2001-2018. Hlutfallið breyttist ekki marktækt á rannsóknartímabilinu $(p=0,896)$.

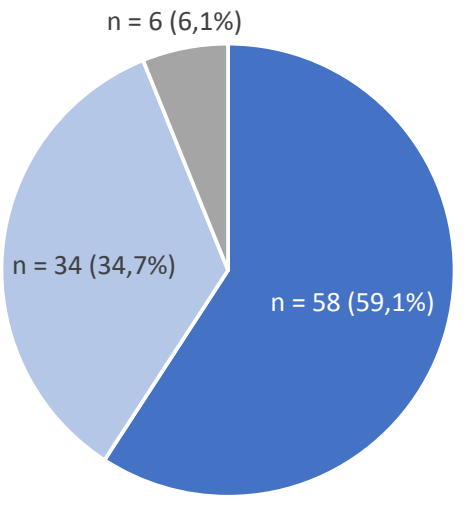

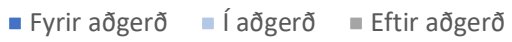

Mynd 2b. Tímasetning á ísetningu ósæðardælu.

\section{Niðurstöður}

Af 2177 sjúklingum sem teknir voru með í rannsóknina fengu 99 (4,5\%) ósæðardælu. Á mynd 2a sést árlegur fjöldi sjúklinga sem fengu dæluna, en tíðnin var hæst 8,9\% árið 2006, en lægst 2,0\% árið 2015. Hlutfall sjúklinga sem fengu dæluna breyttist ekki milli ára $(\mathrm{p}=0,90)$.

Hlutfall sjúklinga sem fengu dæluna í aðgerð hélst mjög svipað á rannsóknartímabilinu og var í kringum 0,0-5,5\% allra sjúklinga ( $\mathrm{p}=0,688)$ eða $34,4 \%$ af peim sem fengu dæluna. Flestir, eða 58 $(58,6 \%)$, fengu dæluna fyrir aðgerð og $6(6,1 \%)$ eftir aðgerð (mynd 2b). Hjá einum sjúklingi (1\%) vantaði upplýsingar um tímasetningu ísetningar.

Í töflu I sést samanburður á sjúklingum sem fengu ósæðardælu og viðmiðunarhópi. Ekki reyndist munur á aldri en marktækt fleiri konur voru í ósæðardæluhópi, eða 30,3\% borið saman við 17,2\%. Ekki reyndist heldur munur milli hópa á tíðni takttruflana fyrir aðgerð, lokusjúkdóma og útæðasjúkdóms, né heldur nýrnastarfsemi og langvinnrar lungnateppu. Hins vegar sást marktækur munur á tíðni hjartabilunar í ósæðardæluhópi, eða $51,5 \%$ á móti 11,6\% í viðmiðunarhópi ( $\mathrm{p}<0,001)$, og í sömu hópum var tíðni nýlegs hjartaáfalls (innan 30 daga fyrir aðgerð) 66,7\% á móti 27,1\% (p<0,001) og tíðni fyrri kransæðavíkkunar með eða án 
Mynd 3. Samanburður á heildarlifun sjúklinga í ósæðardælu- og viðmiðunarhópi (Kaplan Meier) $(p<0,001, \log$-rank próf)

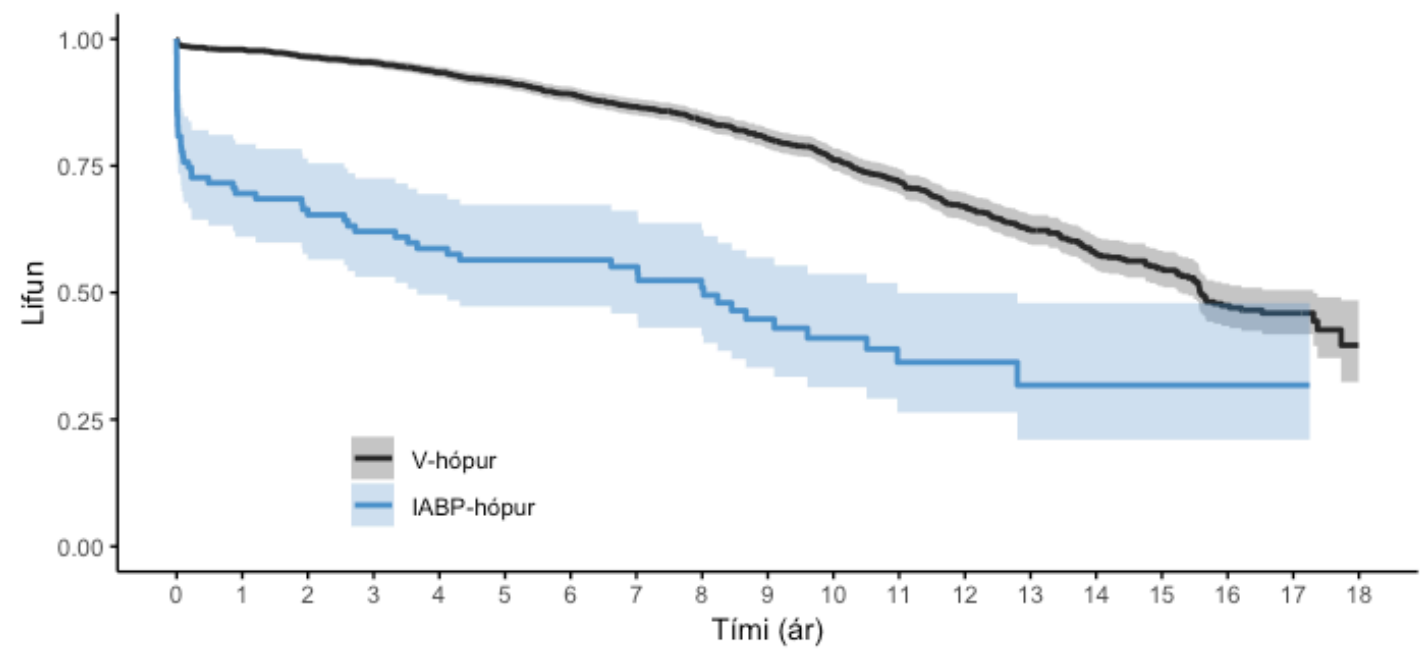

Fjöldi í áhættu (n)

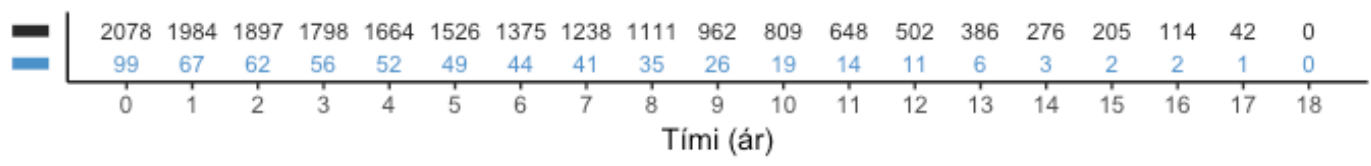

stoðnetsísetningar 11,1\% á móti 23,3\% (p=0,007). Í ósæðardæluhópi voru einkenni sjúklinga, bæði hjartaöng (CCS-flokkur III/IV) og hjartabilunareinkenni (NYHA III/IV), alvarlegri og EuroSCORE

\begin{tabular}{|c|c|c|c|}
\hline & $\begin{array}{l}\text { Ósæðardælu- } \\
\text { hópur } \\
(n=99)\end{array}$ & $\begin{array}{l}\text { Viðmiðunar- } \\
\text { hópur } \\
\text { (n=2078) }\end{array}$ & p-gildi \\
\hline Háprýstingura & $54(56,2)$ & $1371(66,1)$ & 0,060 \\
\hline Blóðfituröskun ${ }^{b}$ & $35(38,5)$ & $1150(56,8)$ & 0,001 \\
\hline Sykursýkic & $19(20,0)$ & $367(17,8)$ & 0,673 \\
\hline Reykingar & $64(64,6)$ & $1471(70,8)$ & 0,231 \\
\hline Fjöldi fjaræðatenginga & & & 0,003 \\
\hline $1-2$ & $7(7,1)$ & $247(11,9)$ & \\
\hline $3-4$ & $74(74,7)$ & $1653(79,5)$ & \\
\hline $5-6$ & $18(18,2)$ & $178(8,6)$ & \\
\hline $\begin{array}{l}\text { LIMA (Left internal mammary } \\
\text { artery) græðlingur notaður }\end{array}$ & $78(78,8)$ & $1976(95,1)$ & $<0,001$ \\
\hline Hopp græðlingur (jump graft) & $53(54,1)$ & $791(39,5)$ & 0,005 \\
\hline Tegund aðgerðar & & & $<0,001$ \\
\hline Með aðstoð HLV & $82(82,8)$ & $1692(81,4)$ & \\
\hline Á sláandi hjarta (OPCAB) & $4(4,0)$ & $349(16,8)$ & \\
\hline Annað & $13(13,1)$ & $37(1,8)$ & \\
\hline Lengd aðgerðare (mín) & $271 \pm 99$ & $211 \pm 53$ & $<0,001$ \\
\hline Vélartímif (mín) & $126 \pm 51$ & $90 \pm 31$ & $<0,001$ \\
\hline Tangartímig (mín) & $54 \pm 20$ & $48 \pm 18$ & 0,004 \\
\hline $\begin{array}{l}\text { Notkun æðahvetjandi lyfja í } \\
\text { aðgerð }^{\text {h }}\end{array}$ & $89(90,8)$ & $1026(49,9)$ & $<0,001$ \\
\hline
\end{tabular}

aUpplýsingar um háprýsting vantađi hjá 7 sjúklingum, bblóđfituröskun hjá 61 sjúklingi, 'sykursýki hjá 15 sjúklingum, ${ }^{d}$ notkun hopp græđlings hjá 23 sjúklingum, elengd ađgerðar hjá 70 sjúklingum, 'vélartíma hjá 368 sjúklingum, `tangartíma hjá 401 sjúklingi og 'notkun æað̌hvetjandi lyfja í aðgerð hjá 23 sjúklingum.

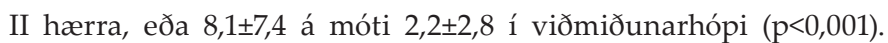
Auk pess var hlutfall sjúklinga með skert útstreymisbrot hærra, eða $43,8 \%$ á móti 3,5\% í viðmiðunarhópi ( $<<0,001)$, en útbreiðsla kransæðasjúkdóms reyndist hins vegar svipuð út frá upplýsingum um hlutfall sjúklinga með priggja æða kransæðasjúkdóm eða vinstri höfuðstofnsprengsl.

Samanburður á helstu áhættupáttum hjarta- og æðasjúkdóma og aðgerðartengdum páttum er sýndur í töflu II. Ekki reyndist munur á áhættupáttum nema hvað blóðfituröskun var algengari í viðmiðunarhópi $(38,5 \%$ á móti $56,8 \% \mathrm{p}=0,001)$. Almennt tóku aðgerðir á sjúklingum í ósæðardæluhópi lengri tíma, hvort sem litið var til heildaraðgerðartíma, tangartíma eða tíma á hjarta- og lungnavél. Hlutfall bráðra aðgerða var 5,4\%, og í peim hópi voru nokkrir sjúklingar sem purftu neyðaraðgerð í kjölfar hjartastopps. Hálfbráðar aðgerðir voru 48,8\% af öllum aðgerðum og hinar gerðar sem valaðgerðir.

Lógistísk aðhvarfsgreining á forspárpáttum pess hvaða sjúklingar fengu ósæðardælu er sýnd í töflu III. Sterkasti forspárpátturinn fyrir notkun ósæðardælu reyndist vera útstreymisbrot vinstri slegils $\leq 30 \%$ (OR =12,84; 95\% ÖB: 4,42-38,03) en aðrir pættir sem spáðu sjálfstætt fyrir notkun ósæðardælu voru kvenkyn, fyrri saga um hjartabilun og CCS-flokkur III/IV.

Tafla III. Forspárpættir fyrir notkun ósæðardælu ákvarðaðir með lógistískri aðhvarfsgreiningu (logistic regression). Gefin eru upp hættuhlutföll (HH) og 95\% öryggisbil (ÖB).

\begin{tabular}{|c|c|c|}
\hline Forspárpáttur & Hrátt HH (95\% ÖB) & Leiðrétt HH $\mathrm{HH}^{\mathrm{a}}(95 \%$ ÖB) \\
\hline Kyn (kvenkyn) & $2,10(1,33-3,23)$ & $3,15(1,40-7,06)$ \\
\hline Hjartabilun & $8,13(5,36-12,36)$ & $2,70(1,18-6,09)$ \\
\hline Útstreymisbrot $\leq 30 \%$ & $37,72(21,16-69,24)$ & $12,84(4,42-38,03)$ \\
\hline CCS-flokkur III/IV & $3,47(1,88-7,16)$ & $3,01(1,15-9,11)$ \\
\hline
\end{tabular}




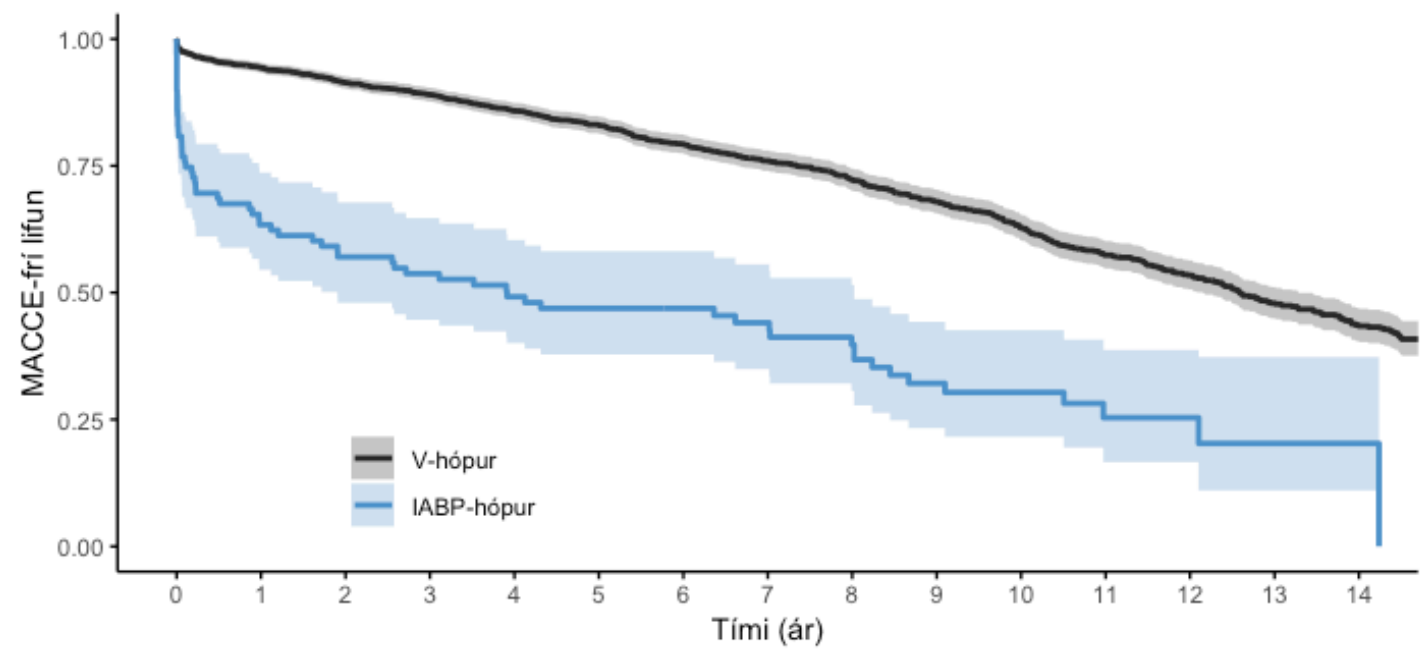

Mynd 4. Samanburður á MACCE- frírri lifun sjúklinga ósæðardælu og viðmiðunarhópi (Kaplan Meier) $(p<0,001, \log -$ rank próf).

Fjöldi i áhættu (n)

\begin{tabular}{|c|c|c|c|c|c|c|c|c|c|c|c|c|c|c|c|}
\hline & 2077 & 1909 & 1793 & 1670 & 1519 & 1373 & 1206 & 1062 & 929 & 784 & 640 & 498 & 384 & 289 & 204 \\
\hline \multirow[t]{2}{*}{ = } & 99 & 61 & 54 & 48 & 43 & 40 & 35 & 31 & 27 & 19 & 14 & 9 & 6 & 3 & 1 \\
\hline & 0 & 1 & 2 & 3 & 4 & 5 & 6 & 7 & 8 & 9 & 10 & 11 & 12 & 13 & 14 \\
\hline
\end{tabular}

Tafla IV sýnir fylgikvilla vegna ísetningar ósæðardælu. Blæðing frá ísetningarstað dælunnar var algengasti fylgikvillinn (4\%) en blóðpurrð í ganglim, sýking á ísetningarstað og bilun á dælu greindust aðeins í einu tilfelli hver (1\%). Enginn sjúklinganna 99 fékk fleiri en einn fylgikvilla samtímis.

Tafla IV. Samanburður skammtíma fylgikvilla, legutíma og 30 daga dánartíðni. Gefin eru upp meðaltöl \pm staðalfrávik eđa fjöldi (\%).

\begin{tabular}{|c|c|c|c|}
\hline & $\begin{array}{c}\text { Ósæðardælu- } \\
\text { hópur } \\
(n=99)\end{array}$ & $\begin{array}{l}\text { Viðmiðunar- } \\
\text { hópur } \\
(n=2078)\end{array}$ & p-gildi \\
\hline Minniháttar fylgikvillar, samtals & $62(62,6)$ & $985(47,4)$ & 0,004 \\
\hline Nýtilkomið gáttatif & $46(46,5)$ & $638(30,7)$ & 0,001 \\
\hline Uppsöfnun á fleiðruvökva & $21(21,2)$ & $259(12,5)$ & 0,017 \\
\hline $\begin{array}{l}\text { Húđsýking (ganglimur/ } \\
\text { bringubein) }\end{array}$ & $11(11,1)$ & $197(9,5)$ & 0,717 \\
\hline \multicolumn{4}{|l|}{ Lungnabólga } \\
\hline \multicolumn{4}{|l|}{$17(17,2)$} \\
\hline $121(5,8)$ & & & $<0,001$ \\
\hline Pvagfærasýking & $13(13,1)$ & $61(2,9)$ & $<0,001$ \\
\hline Alvarlegir fylgikvillar, alls & $38(38,4)$ & $272(13,1)$ & $<0,001$ \\
\hline Hjartadrep í eða eftir aðgerð & $5(5,1)$ & $77(3,7)$ & 0,684 \\
\hline Heilablóðfall & $3(3,0)$ & $20(1,0)$ & 0,143 \\
\hline Bráđur nýrnaskaðia & $6(6,1)$ & $17(0,8)$ & $<0,001$ \\
\hline $\begin{array}{l}\text { Miðmætisbólga með djúpri } \\
\text { bringubeinssýkingu }\end{array}$ & $2(2,0)$ & $18(0,9)$ & 0,525 \\
\hline Fjöllíffærabilun & $21(21,2)$ & $41(2,0)$ & $<0,001$ \\
\hline Bringubeinslos & $6(6,1)$ & $26(1,3)$ & 0,001 \\
\hline Legutími á gjörgæslu (dagar) & $7,1 \pm 7,3$ & $1,7 \pm 2,7$ & $<0,001$ \\
\hline Heildarlegutími (dagar) & $17,2 \pm 14,5$ & $10,5 \pm 7,3$ & $<0,001$ \\
\hline 30 daga dánartíðni & $22(22,2)$ & $28(1,3)$ & $<0,001$ \\
\hline
\end{tabular}

aSkilgreint sem KDIGO flokkur nr. 3. Upplýsingar um bráđan nýrnaskaða vantaði hjá 19 sjúklingum.
Tafla V sýnir samanburð á tíðni skammtímafylgikvilla og legutíma ásamt 30 daga dánartíðni. Marktækt fleiri sjúklingar í ósæðardæluhópi fengu minniháttar fylgikvilla (62,6\% á móti $47,4 \%, p=0,004)$ og sama var upp á teningnum fyrir alvarlega fylgikvilla (38,4\% á móti 13,1\%, p<0,001). Legutími á gjörgæslu og heildarlegutími var marktækt lengri hjá ósæðardæluhópi og auk pess var 30 daga dánartíðni hærri í ósæðardæluhópi (22,2\% á móti $1,3 \%, \mathrm{p}<0,001)$.

Á mynd 3 sést langtímalifun sjúklinga, og var hún verri í ósæðardæluhópi ( $\mathrm{p}<0,001, \log$-rank próf). Heildarlifun eftir eitt ár var 69,5 og 97,9\% í hópunum, 56,4 og 91,5\% eftir 5 ár og 41,0 og $76,2 \%$ eftir 10 ár.

Á mynd 4 sést MACCE-frí lifun í sömu hópum, og var hún sömuleiðis verri í ósæðardæluhópi ( $\mathrm{p}<0,001, \log$-rank próf). Fimm ára MACCE-frí lifun var 46,9\% á móti 83,0\% hjá viðmiðunarhópi.

Tafla V. Tíðni fylgikvilla sem tengdust ísetningu eða notkun ósæðardælu. Gefinn er upp fjöldi sjúklinga (\%). Enginn sjúklingur fékk fleiri en einn fylgikvilla.

\section{Fylgikvilli} Fjöldi (\%)

Blæðing frá ísetningarstað

$4(4,0)$

Blóðpurrð í neðri útlimum

$2(2,0)$

Blóðpurrð annars staðar en í útlimumª

$1(1,0)$

Rof á ósæðardælublöðru

$3(3,0)$

Blóðflögufæð

$2(2,0)$

Sýking á ísetningarstað

$1(1,0)$

Bilun á dælu

$1(1,0)$

Samtals $14(14,1)$

aBlóđpurrð í innri líffærum, í pessu tilviki blóðpurrð í brisi. 'Skilgreind sem fækkun blóðflagna um meira en helming frá upphafsgildum. 


\section{Umræða}

Í pessari afturskyggnu rannsókn fengu 4,5\% sjúklinga á Landspítala ósæðardælu í tengslum við kransæðahjáveitu. Рað er heldur lægra hlutfall en í sambærilegum rannsóknum erlendis par sem hlutfallið er oftast á bilinu 8-20\%, enda pótt bæði hærra (51,8\%) og lægra (2,7\%) hlutfalli hafi verið lýst.,12,19,20 Tíðni notkunar ósæðardælu breyttist ekki marktækt á rannsóknartímabilinu. Niðurstöður okkar eru pví ekki í samræmi við flestar erlendar rannsóknir par sem notkun ósæðardælu hefur minnkað töluvert, ${ }^{8}$ sérstaklega frá birtingu SHOCK II-rannsóknarinnar árið 2012. Par var ekki sýnt fram á gagnsemi ósæðardælu hjá sjúklingum með bráða hjartabilun eftir kransæðastíflu. ${ }^{9}$ Niðurstöður SHOCK II eru hins vegar ekki að fullu yfirfæranlegar á okkar pýði pví hún tók ekki til sjúklinga sem fengu dæluna í eða eftir hjartaaðgerð. Rannsóknir sem einbeita sér að hjartaskurðsjúklingum hafa sumar hverjar lýst ávinningi og í nýlegri safngreiningu (meta-analysis) var sýnt fram á betri horfur hjá há-áhættu sjúklingum sem fengu dæluna fyrir kransæðahjáveitu. ${ }^{13}$

Alls fengu 60\% sjúklinga dæluna fyrir aðgerð í okkar rannsókn, oftast vegna bráđs kransæðaheilkennis, en ákvörðun um að koma fyrir ósæðardælu hjá pessum sjúklingum er yfirleitt tekin af hjartalæknum og peim sem framkvæma hjartapræðingu. Hlutfall sjúklinga sem fékk dæluna fyrir aðgerð breyttist ekki á rannsóknartímabilinu og SHOCK II-rannsóknin virðist pví ekki hafa haft áhrif á ábendingar peirra fyrir notkun dælunnar. Rúmlega priðjungur sjúklinga fékk dæluna hins vegar í aðgerð og pá til að hægt væri að komast af hjarta- og lungnavél. Sú ákvörðun er tekin sameiginlega af hjartaskurðlækni og svæfingarlækni inni á skurðstofu og sama á við um pau 6,1\% sjúklinga sem fengu dæluna eftir að peir voru komnir inn á gjörgæslu. Hlutfall sjúklinga sem fengu dæluna í aðgerð breyttist heldur ekki marktækt á milli ára og notkun dælunnar eftir aðgerð hefur einnig haldist nokkuð svipuð pó enginn sjúklingur hafi fengið ósæðardælu eftir að komið var inn á gjörgæslu á síðustu 11 árum rannsóknartímabilsins.

Helmingi fleiri konur fengu dæluna, eða 7,8\% samanborið við 3,9\% karla. Skýringin á pessu er ekki pekkt en meðalaldur kvenna og karla sem fengu dæluna var sambærilegur pó almennt séu konur eldri en karlar pegar kemur að kransæðahjáveitu ${ }^{14}$ og pví oftar með alvarlegri hjartasjúkdóm. Tíðni hjartaáfalls í ósæðardæluhópi var hins vegar marktækt hærra og útstreymisbrot vinstri slegils oftar skert, auk pess sem fleiri voru með slæma brjóstverki og einkenni hjartabilunar. ${ }^{15,16}$ Petta var viðbúið par sem bráð hjartabilun er langalgengasta ábending fyrir ísetningu ósæðardælu. ${ }^{4}$ Að auki voru marktækt fleiri í peim hópi sem höfðu sögu um kransæðavíkkun með eða án stoðnets, en ósæðardæla er stundum notuð til að fyrirbyggja lost í há-áhættu kransæðavíkkun (high-risk PCI). ${ }^{4}$ Í dag hefur notkun ósæðardælu við áhættu kransæðavíkkanir dregist saman og má sennilega rekja pað til nokkurra slembaðra rannsókna sem ekki hafa getað sýnt fram á betri árangur með notkun dælunnar. ${ }^{21}$ Í staðinn hefur notkun á Impella ${ }^{\circledR}$-hjartadælu aukist víða í Bandaríkjunum og N-Evrópu en um er að ræða eins konar skrúfudælu sem komið er fyrir í inni í vinstri slegli í gegnum náraslagæð og dælir hún blóðinu út í ósæðina. ${ }^{22}$ Impella ${ }^{\circledR}$ hefur verið notuð nokkrum sinnum á Íslandi en er dýr og erlendar rannsóknir hafa ekki getað sannreynt lægra dánarhlutfall en með notkun ósæðardælu. ${ }^{23}$
Par sem sjúklingar í ósæðardæluhópi voru mun veikari en sjúklingar í viðmiðunarhópi var viðbúið að marktækur munur sæist á tíðni skammtímafylgikvilla eftir kransæðahjáveitu milli hópa, bæði hvað varðar minniháttar og alvarlega fylgikvilla. Petta er í samræmi við rannsókn sem sýndi að peir sem purftu á ósæðardælu að halda voru líklegri til pess að próa með sér nýlegt gáttatif eftir aðgerð. ${ }^{24}$

Sjúklingar sem fengu ósæðardælu eftir kransæðahjáveituaðgerð höfðu verri horfur, bæði pegar litið er til skemmri og lengri tíma frá aðgerðinni. Pannig var 30 daga dánartíðni 22,2\% í ósæðardæluhópi borið saman við 1,3\% í viðmiðunarhópi. Pessar tölur endurspeglast í EuroSCORE II fyrir aðgerð sem var fjórfalt hærra í ósæðardæluhópi, eða 8,1\% á móti 2,2\% í viðmiðunarhópi. EuroSCORE II nær hins vegar greinilega ekki að meta áhættu sjúklinga sem fá ósæðardælu par sem raunveruleg dánartíðni í ósæðardæluhópnum var rúmlega helmingi hærri. Tvær erlendar rannsóknir hafa pó sýnt að ósæðardæla hafði engin áhrif á 30 daga dánartíðni hjá sjúklingum með hjartabilun í kjölfar bráðs hjartadreps., ${ }^{9,25}$

Marktækt verri langtímalifun sást fyrir sjúklinga í ósæðardæluhópi, og munaði rúmlega priðjungi 5 árum frá aðgerð. Síðri horfur sjúklinga sem fá ósæðardælu má sennilega að mestu leyti rekja til alvarlegra ástands peirra fyrir aðgerð, oftast alvarlegrar hjartabilunar sem kallaði á notkun dælunnar. Fáar rannsóknir hafa verið gerðar á notkun ósæðardælu með tilliti til langtímalifunar hjá sjúklingum sem gangast undir kransæðahjáveituaðgerð sérstaklega. Flestar rannsóknir hafa sýnt að ósæðardæla tengist ekki verri langtímalifun hjá sjúklingum með STEMI (ST elevation myocardial infarction) og hjartabilun, en hafa ber í huga að eftirfylgdartíminn í flestum peirra er innan við eitt ár. ${ }^{26}$ Einnig eru til rannsóknir sem hafa sýnt fram á að ósæðardæla bæti horfur hjá há-áhættu sjúklingum sem gangast undir kransæðahjáveituaðgerðir. ${ }^{27}$

MACCE-frí lifun reyndist líkt og heildarlifun marktækt síðri í ósæðardæluhópi. Út frá peim niðurstöðum má álykta að síðri heildarlifun ósæðardæluhóps skýrist ekki einungis af hærra dánarhlutfalli í kringum aðgerðina sjálfa heldur einnig af hærri tíðni langtímafylgikvilla sem tengjast hjarta- og æðakerfi. Eldri rannsóknir erlendis hafa pó sýnt að ósæðardæla geti haft jákvæð áhrif hvað varðar MACCE-fría lifun. ${ }^{28-30}$

Almennt var tíðni alvarlegra fylgikvilla ekki há og flestir fylgikvillar sem tengdust dælunni voru minniháttar. Pannig fengu 14,1\% sjúklinga einhvern fylgikvilla tengdan ósæðardælunni og er pað svipað hlutfall og í rannsókn Valente og félaga. ${ }^{31}$ Algengasti fylgikvillinn reyndist vera blæðing frá ísetningarstað og var tíðnin 4,0\%. Aðrir fylgikvillar voru rof á ósæðardælublöðru, blóðpurrð í neðri útlimum og blóðflögufæð en pekkt er að ósæðardælan veldur töluverðu raski á blóðflögum sem getur leitt til blóðflögufæðar. ${ }^{32}$ Einnig sáust dæmi um blóðpurrð í brisi, sýkingu á ísetningarstað og bilun á dælunni, en tíðni pessara fylgikvilla var mjög lág.

Veikleiki við rannsóknina er að hún er afturskyggn, en í slíkum rannsóknum er skráning á fylgikvillum ekki jafn nákvæm og við framskyggna rannsókn. Auk pess er hún óslembuð og pví ekki hægt að meta hvort síðri lifun í ósæðardæluhópnum sé að einhverju leyti vegna dælunnar sjálfrar eða pess ástands sem sjúklingurinn er í pegar meðferðin hefst. Hóparnir sem bornir voru saman voru mjög frábrugðnir og pví var reynt að gera áhættuskorspörun og 
búa til viðmiðunarhóp sem væri sambærilegur með tilliti til bakgrunns sjúklinganna fyrir aðgerð. Pörunin reyndist ekki möguleg vegna smæðar gagnagrunnsins.

Styrkleikar rannsóknarinnar eru að gagnagrunnurinn geymir ítarlegar upplýsingar um hvern og einn sjúkling en hann tekur til allra sjúklinga sem gengust undir kransæðahjáveituaðgerð hjá heilli pjóð á 18 ára tímabili. Auk pess voru aðgerðirnar framkvæmdar á einni stofnun af tiltölulega fáum læknum, sem tryggir einsleitari sjúklingahóp og samræmi á milli aðgerða. Loks er styrkleiki að eftirfylgd var $100 \%$ og brottfall sjúklinga með tilliti til lifunar pví hverfandi.

Rannsóknin sýnir að innan við 5\% sjúklinga fá ósæðardælu í tengslum við kransæðahjáveitu á Íslandi. Algengasti áhættupáttur fyrir notkun dælunnar var alvarleg hjartabilun par sem útstreymisbrot vinstri slegils var verulega skert, eða undir $30 \%$ (eðlilegt 50-60\%). Tíðni fylgikvilla og 30 daga dánartíðni voru eins og búast mátti við hærri hjá sjúklingum sem fengu ósæðardælu, og langtíma- og MACCE-frí lifun peirra umtalsvert síðri, sem skýrist helst af pví að pessir sjúklingar voru mun veikari fyrir aðgerðina frekar en að pað megi reka til notkunar ósæðardælunnar. Pessi rannsókn svarar pví ekki hvort ósæðardæla sé gagnleg eða skaðleg hjá pessum sjúklingum, enda ekki framskyggn. Frekari rannsóknir með stærri sjúklingaefnivið parf til pess, og par væri framskyggn rannsókn æskileg.

\section{Pakkir}

Pakkir fá læknar á hjarta- og lungnaskurðdeild Landspítala og á gjörgæsludeild. Rannsóknin var styrkt af Vísindasjóði Landspítala, Rannsóknarsjóði Háskóla Íslands og Minningarsjóði Helgu Jónsdóttur og Sigurliða Kristjánssonar.

\section{Heimildir}

1. Guðbjartsson T, Andersen K, Danielsen R, Geirsson A, porgeirsson G. Yfirlitsgrein um kransæðasjúkdóm - síðari hluti: Lyfjameðferð, kransæðavíkkun og kransæðahjáveituaðgerð. Læknablaðið 2015; 101: 25-35.

2. Siguriónsson $H$, Helgadóttir $S$, Oddsson SJ, Sigurðsson MI, Geirsson A, Arnórsson P, et al. Árangur kransæðahjáveituaðgerða á Íslandi 2002-2006. Læknablaðið 2012; 98: 451-6.

3. Okonta K, Anbarasu M, Kanagarajan K. Intra-aortic balloon pump in coronary artery bypass graft - factors affecting outcome. J West Afr Coll Surg 2011; 1: 28-40.

4. Parissis H, Graham V, Lampridis S, Lau M, Hooks G, Mhandu PC. IABP: history-evolution-pathophysiology-indications: what we need to know. J Cardiothor Surg 2016; 11: 122.

5. Zacharowski K, Krishna M. Principles of intra-aortic balloon pump counterpulsation. Continuing Educ Anaesthes Criti Care Pain 2009; 9: 24-8.

6. Parissis $\mathrm{H}$, Soo A, Al-Alao B. Intra aortic balloon pump: literature review of risk factors related to complications of the intraaortic balloon pump. J Cardiothor Surg 2011; 6: 147.

7. Elahi MM, Chetty GK, Kirke R, Azeem T, Hartshorne R, Spyt TJ. Complications Related to Intra-aortic Balloon Pump in Cardiac Surgery: A Decade Later. Eur J Vasc Endovasc Surg 2005; 29: 591-4.

8. Gelsomino S, Johnson DM, Lorusso R. Intra-aortic balloon pump: is the tide turning? Critical care (London, England) 2018; 22: 345.

9. Thiele H, Zeymer U, Neumann F-J, Ferenc M, Olbrich H-G, Hausleiter J, et al. Intraaortic Balloon Support for Myocardial Infarction with Cardiogenic Shock. N Engl J Med 2012; 367: 1287-96.

10. Dharma S, Dakota I, Firdaus I, Wardeh AJ, Jukema JW. The Use of Intra-aortic Balloon Pump in a Real-World Setting: A Comparison between Survivors and Nonsurvivors from Acute Coronary Syndrome Treated with IABP. The Jakarta Acute Coronary Syndrome Registry. Int J Angiol 2013; 22: 213-22.

11. Thiele H, Zeymer U, Thelemann N, Neumann F-J, Hausleiter J, Abdel-Wahab M, et al. Intraaortic Balloon Pump in Cardiogenic Shock Complicating Acute Myocardial Infarction. Circulation 2019; 139: 395-403.

12. Theologou T, Bashir M, Rengarajan A, Khan O, Spyt T, Richens D, et al. Preoperative intra aortic balloon pumps in patients undergoing coronary artery bypass grafting. Cochrane Database Syst Rev 2011: (1): CD004472.
13. Deppe A-C, Weber C, Liakopoulos OJ, Zeriouh M, Slottosch I, Scherner M, et al. Preoperative intra-aortic balloon pump use in high-risk patients prior to coronary artery bypass graft surgery decreases the risk for morbidity and mortality-A meta-analysis of 9,212 patients. J Cardiac Surg 2017; 32: 177-85.

14. Garðarsdóttir HR, Árnadóttir LÓ, Aðalsteinsson JA, Jóhannesdóttir $\mathrm{H}$, Helgadóttir S, Hrafnkelsdóttir PJ, et al. Árangur kransæðahjáveituaðgerða hjá konum á Íslandi. Læknablaðið 2018; 104: 335-40.

15. Campeau L. Letter: Grading of angina pectoris. Circulation 1976; 54: 522-3.

16. Dolgin $\mathrm{M}$, New York Heart Association. Criteria Committee. Nomenclature and criteria for diagnosis of diseases of the heart and great vessels In: Dolgin M, editor. 9 ed. Little, Brown, Boston 1994.

17. Nashef SA, Roques F, Sharples LD, Nilsson J, Smith C, Goldstone AR, et al. EuroSCORE II. Eur J Cardio-thor Surg 2012; 41: 734-44; discussion 44-5.

18. RStudio Team. RStudio: Integrated Development for R. RStudio, Inc, Boston 2016.

19. Dietl CA, Berkheimer MD, Woods EL, Gilbert CL, Pharr $\mathrm{WF}$, Benoit $\mathrm{CH}$. Efficacy and cost-effectiveness of preoperative IABP in patients with ejection fraction of 0.25 or less. Ann Thorac Surg 1996; 62: 401-8; discussion 8-9.

20. Danielsen R, Guðnason P, Guðmundsdóttir IJ. Kransæðavíkkun. In: Guðbjartsson T, Porgeirsson G, ritstj. Kransæðabókin. Reykjavík 2016.

21. Perera D, Stables R, Thomas M, Booth J, Pitt M, Blackman $\mathrm{D}$, et al. Elective Intra-aortic Balloon Counterpulsation During High-Risk Percutaneous Coronary Intervention: A Randomized Controlled Trial. JAMA 2010; 304: 867-74.

22. Amin AP, Spertus JA, Curtis JP, Desai N, Masoudi FA, Bach RG, et al. The Evolving Landscape of Impella ${ }^{\circledR}$ Use in the United States Among Patients Undergoing Percutaneous Coronary Intervention with Mechanical Circulatory Support. Circulation 2019 Nov 17.

23. Schrage B, Ibrahim $K$, Loehn $T$, Werner N, Sinning J-M, Pappalardo F, et al. Impella Support for Acute Myocardial Infarction Complicated by Cardiogenic Shock. Circulation. 2019; 139: 1249-58.

24. Shirzad M, Karimi A, Tazik M, Aramin H, Hossein Ahmadi S, Davoodi S, et al. Determinants of postoperative atrial fibrillation and associated resource utilization in cardiac surgery. Rev Espan Cardiologia 2010; 63: 1054-60.
25. Su D, Yan B, Guo L, Peng L, Wang X, Zeng L, et al. Intraaortic balloon pump may grant no benefit to improve the mortality of patients with acute myocardial infarction in short and long term: an updated meta-analysis. Medicine 2015; 94: e876-e.

26. Dziewierz A, Siudak Z, Rakowski T, Kleczyński P, Zasada W, Dudek D. Impact of intra-aortic balloon pump on long-term mortality of unselected patients with ST-segment elevation myocardial infarction complicated by cardiogenic shock. Postepy Kardiol Interwencyjnej 2014; 10: 175-80.

27. Wan Y-D, Sun T-W, Kan Q-C, Guan F-X, Liu Z-Q, Zhang S-G. The Effects of Intra-Aortic Balloon Pumps on Mortality in Patients Undergoing High-Risk Coronary Revascularization: A Meta-Analysis of Randomized Controlled Trials of Coronary Artery Bypass Grafting and Stenting Era. PloS one 2016; 11: e0147291-e.

28. Rampersad PP, Udell JA, Zawi R, Ouzounian M, Overgaard CB, Sharma V, et al. Preoperative Intraaortic Balloon Pump Improves Early Outcomes Following HighRisk Coronary Artery Bypass Graft Surgery: A MetaAnalysis of Randomized Trials and Prospective Study Design. J Invasive Cardiol 2018; 30: 2-9.

29. Rampersad PP, Zawi R, Overgaard CB, Ouzounian $M$ Sharma V, Rao V, et al. Preoperative intra-aortic balloon pump (IABP) decreases mortality and major adverse cardiovascular and cerebrovascular events (MACCE) in high-risk coronary artery bypass (CABG) patients. Can J Cardiol 2015; 31: S179-S80.

30. Wilczynski M, Krzych LJ, Bis J, Szmagala P, Ulczok R, Bochenek A. Effect of gender on efficacy of preoperative intra-aortic balloon pump in high risk patients undergoing surgical coronary revascularisation. Kardiol Pol 2010; 68: 1361-8.

31. Valente S, Lazzeri C, Crudeli E, Chiostri M, Giglioli C, Bernardo $\mathrm{P}$, et al. Intraaortic balloon pump: incidence and predictors of complications in the Florence registry. Clinical cardiol 2012; 35: 200-4.

32. Krishna M, Zacharowski K. Principles of intra-aortic balloon pump counterpulsation. BJA Education 2009; 9: 24-8 


\section{The use of Intra Aortic Balloon Pump in Coronary Artery Bypass Graft Surgery}

Sunna Lu Xi Gunnarsdóttir ${ }^{1}$ Erla Liu Ting Gunnarsdóttir ${ }^{1}$ Alexandra Aldís Heimisdóttir ${ }^{1}$ Sunna Rún Heiðarsdóttir ${ }^{1}$ Sólveig Helgadóttir ${ }^{2}$ Martin Ingi Sigurðsson ${ }^{1,3}$ Tómas Guðbjartsson ${ }^{1,4}$

Introduction: Intra-aortic balloon pump (IABP) is a mechanical device that increases cardiac output by increasing diastolic blood flow to the coronary arteries and lowers the afterload of the left ventricle in systole. IABP is primarily used in acute heart failure, that includes patients that have to undergo coronary artery bypass grafting (CABG). Its usage, however, in cardiac surgery has been declining with ongoing controversy regarding its benefits. The aim of this study was to assess the use and indications and outcome of IABP related to CABG surgery.

Material and Methods: The study was retrospective and included 2177 patients that underwent CABG at Landspítali during 20012018. We compared those who received an IABP with controls, using uni- and multivariate analysis. Long term survival and complications (major adverse cardiovascular and cerebral events, MACCE) was estimated with Kaplan-Meier method.

Results: A total of 99 (4.5\%) patients received an IABP. The incidence was highest in 2006 (8.9\%) and lowest in 2001 (1.7\%), but the incidence did not change during the study period $(p=0.90)$. Most patients received the pump before $(58.6 \%)$ or during (34.3\%) CABG, but only $6.1 \%$ after surgery. Complication rate was $14.1 \%$, with bleeding from the insertion site in the groin being the most common complication. Thirty day mortality was higher in the IABP group compared with controls $(22.2 \%$ vs $1.3 \%, p<0.001)$ and both 5 -year survival (56.4\% vs $91.5 \%, 95 \% \mathrm{Cl}: 0.47-0.67)$ and 5-year MACCE-free survival (46.9\% vs $83.0 \%, 95 \% \mathrm{Cl}$ : $0.38-0.58)$ were inferior. Conclusions: Less than $5 \%$ of patients received IABP in relation to $\mathrm{CABG}$ in Iceland and the rate hasn't changed much for the last 18 years. Both the complication rate and 30-day mortality was higher in patients in IABP group and both the long term and MACCE-free survival was much worse, probably mostly related to worse overall clinical condition of the patient that received IABP.

${ }^{1}$ Faculty of Medicine, University of Iceland, ${ }^{2}$ Department of Anesthesia and Intensive Care, Akademiska University Hospital, Uppsala, Sweden, ${ }^{3}$ Departments of Anesthesia and Intensive Care, ${ }^{4}$ Cardiothoracic surgery, Landspitali University Hospital, Reykjavik, Iceland.

Key words: Intra-aortic balloon pump, coronary artery bypass graft (CABG), indications, complications, outcome, survival.

Correspondence: Tómas Guðbjartsson, tomasgudbjartsson@hotmail.com 